\title{
OR13-003 - TNFRSF11A molecular defects cause autoinflammatory disorders
}

\author{
I Jéru ${ }^{1,2,3^{*}}$, E Cochet $^{3}$, P Duquesnoy ${ }^{1}$, V Hentgen ${ }^{4}$, B Copin ${ }^{1}$, M Mitjavila-Garcia ${ }^{5}$, S Sheykholeslami ${ }^{1}$, G Le Borgne ${ }^{1,2}$, \\ F Dastot $^{1,3}$, S Karabina ${ }^{1,2}$, M Mahevas ${ }^{6}$, S Chantot-Bastaraud ${ }^{1}$, L Faivre ${ }^{7}$, S Amselem ${ }^{1,2,3}$ \\ From 7th Congress of International Society of Systemic Auto-Inflammatory Diseases (ISSAID) \\ Lausanne, Switerland. 22-26 May 2013
}

\section{Introduction}

Hereditary recurrent fevers (HRF) are autoinflammatory disorders whose etiology remains unknown in many cases.

\section{Objectives}

To identify a new HRF gene

\section{Methods}

Comparative genomic hybridization (CGH, 385K array) was performed in the proband. TNFRSF11A was screened by Sanger sequencing in other patients. TNFRS11A expression was quantified by fluorescence-activated cell sorter analysis (FACS). NF-k B activation was assessed using a luciferase assay in HEK293 cells transfected with plasmids encoding wild-type and mutated TNFRSF11A.

\section{Results}

Array-CGH analysis performed in a patient with multiple congenital anomalies and a recurrent fever syndrome revealed a de novo heterozygous chromosomal rearrangement encompassing a duplication of TNFRSF11A. This transmembrane receptor binds the TNFSF11 cytokine, activates NF-k B signaling, and regulates fever in rodents, consistent with a possible role in HRF. TNFRSF11A screening in other patients with genetically-unexplained HRF revealed a heterozygous frameshift mutation in a patient and her affected mother. The mutated protein is expressed at similar levels as the normal receptor on leukocytes. Most importantly, this mutation results in a gain of function on NF-k B signaling, since the mutated protein is more responsive to TNFSF11 stimulation than the wildtype receptor. Since TNFRSF11A (also known as RANK) was previously known for its key role in osteoclastogenesis, the medical history of our patients was reassessed and revealed minor symptoms also found in patients with TNFRSF11A-associated bone disorders.

\section{Conclusion}

The implication of TNFRSF11A in HRF reveals a key role of this receptor in autoinflammation and opens up new fields of research at the crossroads between bone metabolism and innate immunity.

\section{Disclosure of interest}

None declared.

\section{Authors' details}

'UMR_S933, INSERM, France. ${ }^{2}$ Université Pierre et Marie Curie-Paris, France. ${ }^{3} G$ Génétique et d'Embryologie Médicales, Hôpital Trousseau, Paris, France. ${ }^{4}$ Centre de Référence des Maladies Autolnflammatoires (CeRéMAl), Centre Hospitalier de Versailles, Le Chesnay, France. ${ }^{5}$ U.935, INSERM, Villejuif, France. ${ }^{6}$ Médecine Interne, Hôpital Henri Mondor, Créteil, France. ${ }^{7}$ Centre de Génétique et Centre de Référence Anomalies du Développement et Syndromes Malformatifs, Hôpital d'Enfants, Dijon, France.

Published: 8 November 2013

doi:10.1186/1546-0096-11-S1-A265

Cite this article as: Jéru et al.: OR13-003 - TNFRSF11A molecular

defects cause autoinflammatory disorders. Pediatric Rheumatology 2013 11(Suppl 1):A265. 